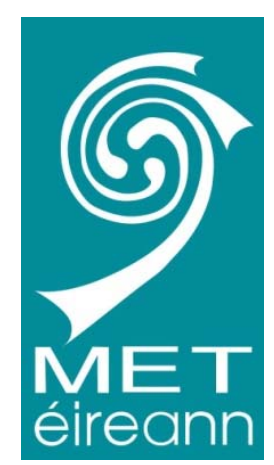

Title: Agricultural Meteorology in Ireland - a historical perspective from the Irish Meteorological Service

Author(s) and affiliations: Agricultural Meteorology Unit. Research, Environment and Applications Division. Met Éireann - The Irish Meteorological Service, Dublin, Ireland

This article is provided by the author(s) and Met Éireann in accordance with publisher policies. Please cite the published version.

NOTICE: This is the author's version of a work that was accepted for publication in BIOLOGICAL RHYTHM RESEARCH. Changes resulting from the publishing process such as editing, structural formatting, and other quality control mechanisms may not be reflected in this document. Changes may have been made to this work since it was submitted for publication. A definitive version was subsequently published in Biological Rhythm Research ISSN: 0929-1016 (Print) 1744-4179 (Online) Journal homepage: http://www.tandfonline.com/loi/nbrr20

Citation: Keith Lambkin (2018): Agricultural Meteorology in Ireland - a historical perspective from the Irish Meteorological Service, Biological Rhythm Research, DOI: $10.1080 / 09291016.2018 .1518870$

This item is made available to you under the Creative Commons Attribution-Non commercial-No Derivatives 3.0 License.

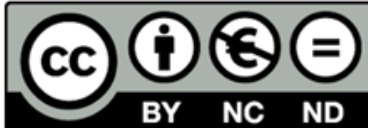




\section{Agricultural Meteorology in Ireland - a historical perspective from the Irish Meteorological Service}

\section{Keith Lambkin}

To cite this article: Keith Lambkin (2018): Agricultural Meteorology in Ireland - a historical perspective from the Irish Meteorological Service, Biological Rhythm Research, DOI:

10.1080/09291016.2018.1518870

To link to this article: https://doi.org/10.1080/09291016.2018.1518870

册Published online: 03 Oct 2018.

Submit your article to this journal

Џ Article views: 3

View Crossmark data \lceil 


\title{
Agricultural Meteorology in Ireland - a historical perspective from the Irish Meteorological Service
}

\author{
Keith Lambkin
}

Head of Agricultural Meteorology Unit.Research, Environment and Applications Division. Met Éireann - The Irish Meteorological Service, Dublin, Ireland

\begin{abstract}
Ireland has a temperate climate influenced by the Atlantic Gulf Stream. This, combined with fertile soils and adequate rainfall, provides an environment ideally suited for grass. Grass is an inexpensive, nutritious feed for livestock, giving Ireland a competitive advantage in this sector. Tillage farming is also an important sector for Ireland, and evidence of the Great Irish Famine of the mid-eighteen hundreds is still visible in the landscape. In this paper, we examine aspects of meteorological involvement in Irish agriculture, from the perspective of the Irish Meteorological Service. We examine the rise of agrometeorology in Ireland and take a look at the development of related services, including potato blight warnings. Two influential characters of Irish agrometeorological history, Austin Bourke and Tom Keane, are examined, as well as organisations such as the AGMET Group. The paper concludes with a brief snapshot of current Irish agrometeorological activities along with future ambitions.
\end{abstract}

\section{ARTICLE HISTORY}

Received 1 July 2018

Accepted 20 August 2018

\section{KEYWORDS}

Agriculture; meteorology; Ireland; history

\section{The Great Famine}

In 1845, potato blight spread widely throughout Western Europe. The disease (phytophthora infestans) was not familiar to farmers and scientists at the time. Weather conditions were conducive to spread windborne blight spores to much of Ireland, Britain, France, Belgium and the Netherlands. Almost half of the potato crop in Ireland failed that year. The following year, this staple crop which Ireland had become so dependent on completely failed (Nelson 1995). The result was catastrophic. One million people died of starvation, while another one million were forced to leave their homes and emigrate, many to America, in an attempt to save their families. This crop failure had the net effect of reducing the population of Ireland by $25 \%$ in just a few years (Kinealy 1994). Stories of the Irish potato famine live on in current memories as a stark reminder of the dependence of agriculture on the weather. The meteorological factors relating to the spread of potato blight would later be examined by the Irish Meteorological Service.

CONTACT Keith Lambkin keith.lambkin@met.ie E Head of Agricultural Meteorology Unit.Research, Environment and Applications Division. Met Éireann - The Irish Meteorological Service, Glasnevin Hill, Dublin 9, Ireland 


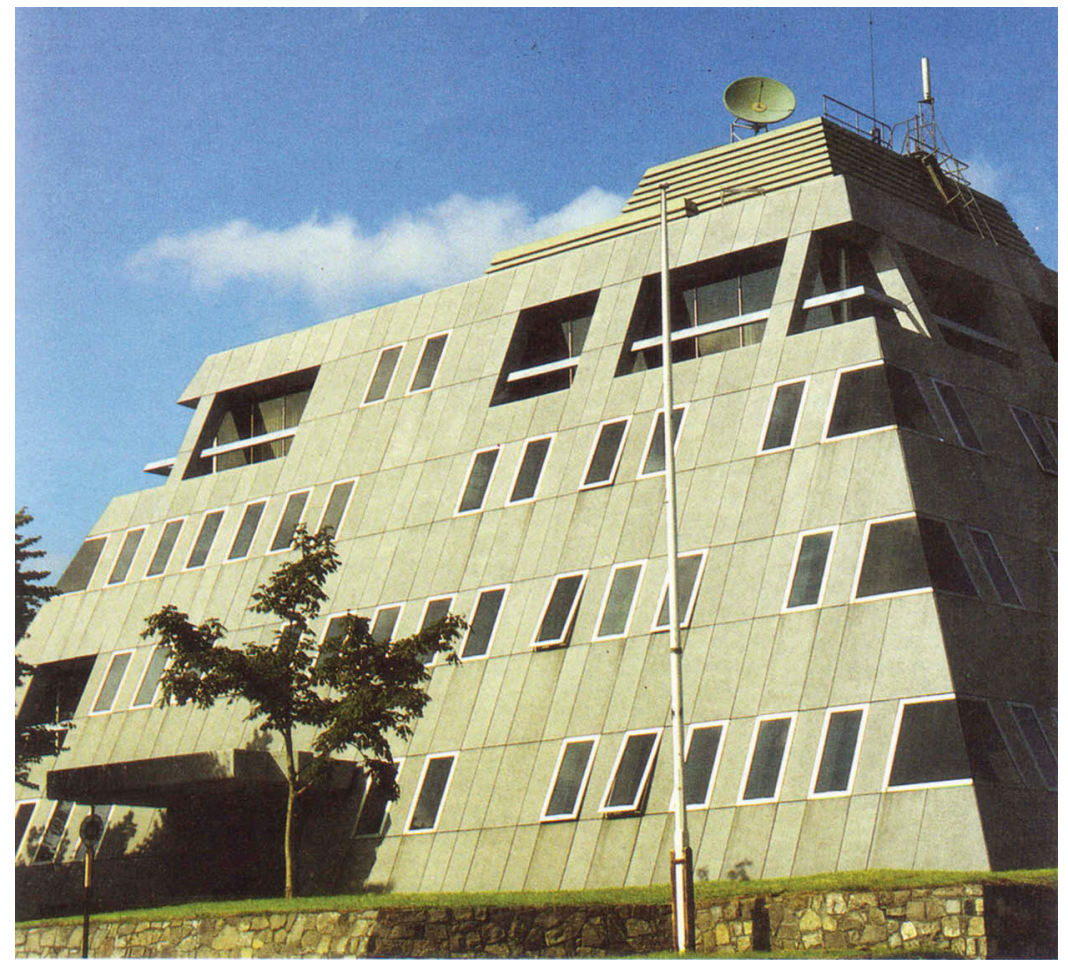

Figure 1. The Irish Meteorological Service headquarters in Glasnevin, Dublin. This image was taken shortly after the Service moved to its new home in 1979. [Photo: J. Hamilton].

\section{The Irish Meteorological Service}

The Irish Meteorological Service was established in December 1936 (T. Keane, Establishment of the Meteorological Service in Ireland. The Foynes Years, 1936-1945 2012). Its first objective was to take over meteorological operations from the British Meteorological Office. The official transfer of meteorological responsibilities for the Republic of Ireland to the new service took place on the 1 April 1937. At that moment, the service was made up of Valentia Observatory, four telegraph reporting stations, 18 climatological stations and 172 rainfall stations. The appointed director of the new Irish Meteorological Service was Austen H. Nagle, a graduate of the University of London and a serving officer of the British Meteorological Office at the time. He was later replaced by Mariano Doporto in 1948 who, following his sudden death in Dublin in September 1964, was replaced by Austin Bourke (Shields 1987).

\section{Austin Bourke}

Austin Bourke is one of two individuals mentioned in this paper who had a profound influence on Irish agrometeorology. He was born in 1913 and, at the age of 20, graduated from University College Cork winning the Peel Memorial Prize as outstanding graduate of the year (Shields 1987). He later went on to obtain an MSc (first class honours) and two 


\section{Asmet}

Figure 2. AGMET Logo. The Joint Working Group on Applied Agricultural Meteorology (AGMET) was established in 1984 by Tom Keane and others in an attempt to unite the agrometeorological community in Ireland.

doctorates, the second doctorate being an honorary DSc from the National University of Ireland for his contributions to agrometeorology at home and abroad.

Bourke was one of the first meteorological cadets recruited by the Irish Meteorological Service in 1939. Over the course of his career, he made a particular mark on agricultural meteorology, but his special focus was on potato blight.

Working with other government agencies, Bourke developed a simplified set of weather rules to predict the likely onset of potato late blight. This enabled the Meteorological Service to begin issuing blight warnings from 1953 (Bourke, The potato blight weather warning service in Ireland in 1952 1953). Having proved successful, the model, which became known as the "Bourke model" or "Irish rules" for the forecasting of potato late blight, was later adopted by other countries. The Irish Meteorological Service continue to this day to issue these blight warnings along with advice on the best spraying opportunities in the days ahead. Bourke also devoted much of his time to researching the origins of the Great Famine (Bourke, The Visitation of God, The Potato and the Great Irish Famine 1993), (Bourke and Lamb, The Spread of Potato Blight in Europe in 1845-6 and the Accompanying Wind and Weather Patterns 1993).

From 1958 to 1962, Austin Bourke served as president to the World Meteorological Service (WMO) Commission for Agricultural Meteorology. In 1964, he was promoted to the director of the Irish Meteorological Service, and perhaps it is of no surprise that the following year (1965), he established a dedicated "Agricultural Meteorology Unit" to support the weather-related needs of the Irish agricultural community (Irish Meteorological Service 1965).

\section{The Agricultural Meteorology Unit}

The Agricultural Meteorology Unit is a unit within the Irish Meteorological Service. Still active today, the unit operates in close collaboration with agricultural scientists and advisors across a broad range of agriculture in Ireland including soil science, livestock, farm management, horticulture and veterinary science. With the establishment of the unit, momentum in agrometeorology began to build. Research into topical issues led to the publications of "Agrometeorological Memorandum", by the unit from 1968 to 1982. This series covered topics such as soil moisture deficits (Connaughton, Soil moisture deficits in Ireland in summer 1968 1969), soil temperatures (Connaughton, Soil temperatures in Ireland 1970), frost (Connaughton, Air frosts in late autumn and early winter 1973), grass growth (Connaughton, The grass-growing season in Ireland 1973) and of course potato blight (T. Keane, Weather and potato blight 1982). In 1971, the "Agrometeorological Bulletin" began (Irish Meteorological Service - Met Éireann 1971). These proved very popular with farmers and continued right up to 1990 when they were incorporated into a larger climate bulletin which is still published monthly today. 


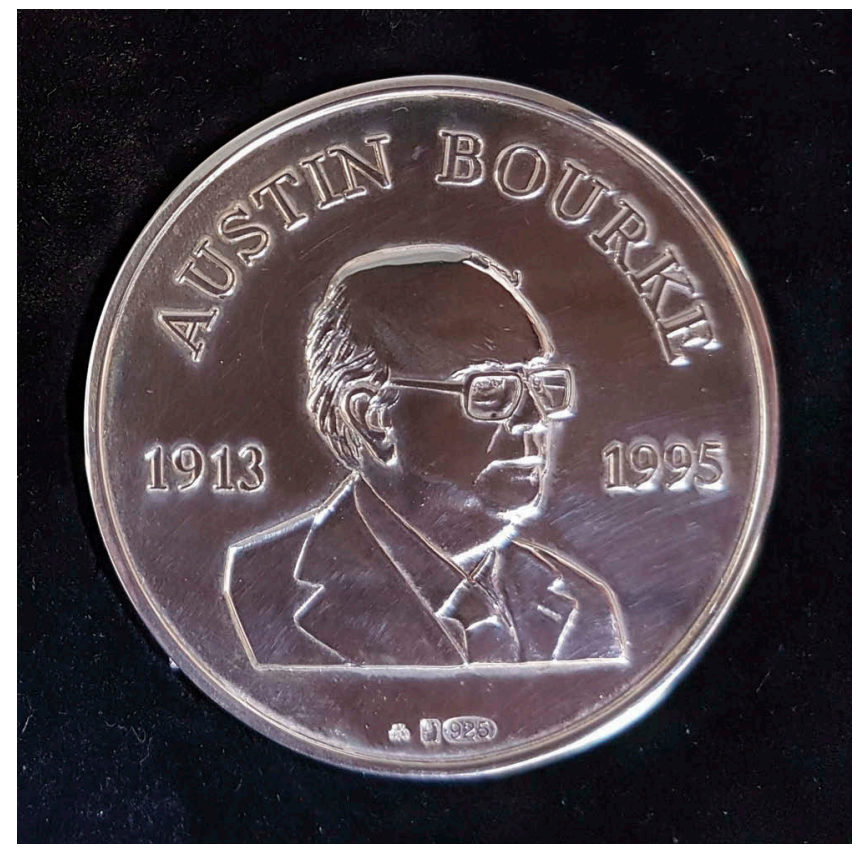

Figure 3. Austin Bourke is commemorated on the "Bourke Silver Medal" which is awarded by the AGMET Group to individuals who have displayed long-term outstanding contributions to the area of agricultural meteorology. [Photo K. Lambkin].

In the 1960s, Austin Bourke established four sites as part of the International Phenology Gardens programme (Donnelly et al. 2013). By continually monitoring growing phases of these cloned trees, evidence of climate change could be observed. The decades of dedicated monitoring of these special trees from all over Europe have proved an invaluable observational dataset in the study of climate change (Koch et al. 2009).

During the 1970s, the unit participated in an "Advisory Group on Liver Fluke", which was established by the Department of Agriculture. Research had shown that the number of animal livers condemned at abattoirs with fluke damage was correlated to the Ollerenshaw Index (Ollerenshaw 1966), (Thomas 1978). From this an operational liver fluke severity forecast was established to warn, primarily cattle and sheep famers, in advance and to provide advice on appropriate vaccination strategies. The Advisory Group, supported by the analysis of the Agricultural Meteorology Unit, still produce annual press releases advising on expected liver fluke severity and avoidance practices.

During this time, the unit also collaborated in research areas including maize growth related to weather, the quality of hops to mean air temperatures and in the area of soil temperatures (Irish Meteorological Service 1975).

The year 1979 was significant for the Irish Meteorological Service. It was in this year that it moved to its current headquarters in Glasnevin, Dublin (Figure 1). It was also in this year that the Agricultural Meteorology Unit began providing the Irish farming press with tailored agricultural-related weather forecasts. 


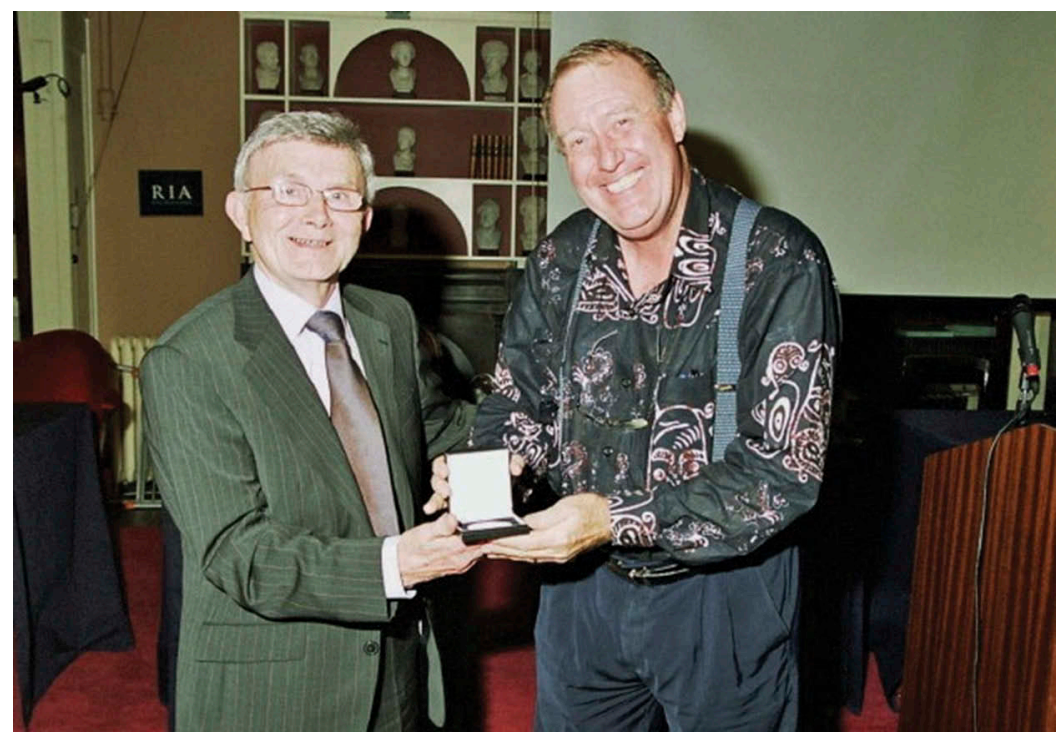

Figure 4. Tom Keane is presented with the Bourke Silver Medal by Kees Stigter at the Royal Irish Academy in 2006. [Photo: AGMET].

The 1980s saw further enhancements to agrometeorological services. In 1983, Ireland's "Agricultural Institute" (now Teagasc) launched a weather-driven grass growth model (Irish Meteorological Service 1983).

This was also the period when the Agricultural Meteorology Unit launched a fire weather warning index to advise the forestry service of potential fire risk. Based on the Canadian Forest Fire Weather Index model, this product is today embedded in national emergency decision support infrastructures.

With all of these new products and services becoming mainstream, the farming community were becoming data hungry. By the mid-1980s, $40 \%$ of all call queries to the Irish Meteorological Service were agricultural related (Irish Meteorological Service 1984).

\section{Tom Keane and the AGMET Group}

Another hugely influential character in Irish agrometeorology history is a man by the name of Tom Keane. Keane joined the Meteorological Service in 1954, and following postings at Valentia Observatory and Shannon Airport, he was transferred to the then headquarters in O'Connell Street, Dublin in 1972. From here, Keane became the Head of the Agricultural Meteorology Unit. It became clear to Keane that with the ever-increasing availability of meteorological information, the arrival of satellite products and the increase in number and diversity of agricultural models, more could be achieved by strengthening the agrometeorological community in Ireland.

In 1984, he founded the "AGMET Group", or to give it its full title, the "Joint Working Group on Applied Agricultural Meteorology" (AGMET 1985). Still active, AGMET (Figure 2) is a voluntary organisation which acts as a hub for the agrometeorology community in Ireland. Members, mostly professionals in agriculture-related disciplines, collectively define 


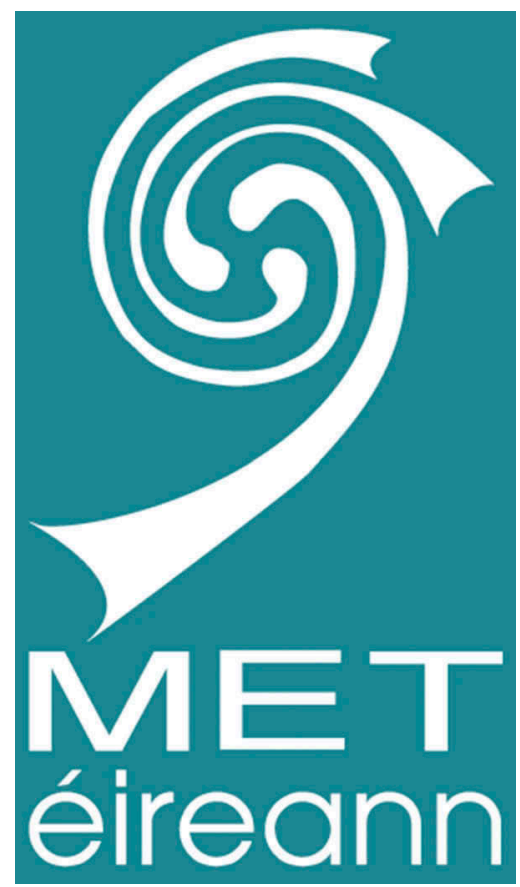

Figure 5. The Irish Meteorological Service rebranded as "Met Éireann" in 1996. In the national language Gaeilge, "Éireann" translates to mean "Ireland".

national agrometeorological requirements and then endeavour to align their individual organisations towards achieving these common objectives. The AGMET Group's ultimate aim is to help make better use of meteorology in Irish agriculture. Over the next 30 years, Keane, as convener of the AGMET Group, along with other very well-established professionals in the area, would help drive Irish agriculture meteorology forward.

The group published a number of books including: "Climate, Weather and Irish Agriculture" (Keane and Collins 2004), "Agro-Meteorological modelling - Principles, Data and Applications" (Holden 2001) and the "Agroclimatic Atlas of Ireland" (Collins and Cummins 1996). Some of these books became core references for university courses and hence became an important income stream to the AGMET Group.

A change that required new farm entrants to undergo a formal educational course entitled a "Certificate in Farming" led the AGMET Group to produce the handbook "Weather and Agriculture". The Group also gave the course education officers a series of lectures on relevant topics.

Agrometeorological conferences were regularly held by AGMET, and the conference proceeding from most of these were published. These became valuable networking opportunities as well as a way to introduce younger researchers to the community. A number of special reports were also commissioned by the Group including Cold Stress on Sheep (Dozeman 2001) as well as a review of the AGMET Group in 2001 (Murphy and Holden 2001).

The Group also commissioned two types of awards, both named after Austin Bourke. The Bourke silver medal (Figure 3) is awarded by AGMET for long-term outstanding contributions to the area of agricultural meteorology. The Bourke bronze medal is awarded for a specific 
outstanding contribution to the area of agricultural meteorology. The inaugural silver medal was presented to Austin Bourke's wife in 2004. Other recipients included Anthony Brereton (Teagasc and UCD) largely for his contributions to grassland management and agrometeorological models; James Collins (UCD, Agriculture, Food and Veterinary College) largely for his contributions to soil science as well as decades of involvement with the AGMET Group; and Tom Keane himself (Figure 4).

Through his work in agrometeorology, Keane was promoted to Head of the Research and Applications Division within the Irish Meteorological Service in 1994, where he remained until his retirement in 1999.

\section{6. $1985-2010$}

In parallel to the much-welcomed work of the AGMET Group, The Agricultural Meteorology Unit of the Irish Meteorological Service continued to pursue collaborations and to develop products and services. In 1985, Ireland's Department of Agriculture purchased a foot and mouth disease dispersion model, which the Agricultural Meteorology Unit installed, hosted and made operational through the use of weather forecasts (Irish Meteorological Service 1986). During the late 1980s, the unit was incorporated into a reorganised Climate and Observations Division within the Meteorological Service. The aim was to aid in the development of an appropriate database adequate to quickly reply to the increasing climate observation requests, largely by the agricultural community.

Annual attendance by the Meteorological Service at the National Ploughing Championships became standard practice. What was originally a ploughing competition which began in 1931 (National Ploughing Association 2017), the event has now become a trade show for anything even vaguely agricultural related. Typically attracting over 250,000 people over a three-day event each September, it proves to be an invaluable source of feedback from farmers on Ireland's agrometeorological products and services.

Outside of the Meteorological Service, other agriculture and advisory services were brought together into a single organisation called the "Agricultural and Food Development Authority", or "Teagasc", as it is more commonly known. During this time, there was a noticeable increase in the level of grass-related studies by Teagasc. More accessible computers saw the introduction of models related to crop yields and the Teagasc research centre in Oak Park began taking advantage of remote sensing products (Irish Meteorological Service 1991). Teagasc continued their research into slurry spreading, work that would later prove valuable relating to the EU Nitrates Directive.

University College Dublin were also active in agrometeorological research. The probability of two dry-day periods for silage making and four dry-day periods for peat extracting were calculated. The meteorological relations between crop, livestock, pests and diseases were studied, as well as effects of soil temperatures and moisture on ammonia volatilisation. University College Cork were researching meteorological aspects related to plant biology and disease, while University College Galway were contributing to our understanding of pollution of the biosphere and its relationship to airborne plant nutrients for forestry (Irish Meteorological Service 1991).

With so many stakeholders with a vested interest in agrometeorology, the AGMET Group proved invaluable in preventing duplication and in promoting collaborations. 


\section{Current snapshot}

The Irish Meteorological Service, or "Met Éireann", as it is now know after its rebranding in 1996 (Figure 5), still has an Agricultural Meteorology Unit. The head of the unit still acts as convener of the AGMET Group. In 2015, Met Éireann and the AGMET Group held an Agricultural Meteorology Seminar, attended by relevant stakeholders (AGMET 2017). The outputs of this seminar has helped to identify and prioritise the current needs of the Irish agrometeorology community. This has helped focus limited resources to try and achieve the maximum benefit.

The Agricultural Meteorology Unit continues to maintain legacy products and services that are deemed to still have value, including for example liver fluke severity forecasts and fire warning indices. Efforts have been made to make legacy products accessible online. For example, a daily farming weather forecast product, which is now digitally available, currently receives 25 times the readership that its equivalent fax-based product did.

The foot and mouth disease model has been completely rebuilt and modernised, driven largely by Irish modifications to the NOAA HYSPLIT dispersion model (Stein et al. 2016), initialised by European Centre for Medium-Range Weather Forecasts (ECMWF) and local area weather forecasts.

A blue tongue virus model is currently being developed by the Agricultural Meteorology Unit in collaboration with The Centre for Veterinary Epidemiology and Risk Analysis (CEVRA).

The unit is collaborating in research projects with Teagasc and the Department of Agriculture on areas including grass growth, evapotranspiration, soil moisture deficits and of course potato blight. Many decades have passed since Austin Bourke developed his "Irish rules" to forecast blight in Ireland. In this time, the blight pathogen has mutated, and the potato crop has undergone change. We are revisiting Bourke's legacy to investigate if improvements can be made more relevant to the current climate and crop.

Met Éireann continues to attend the National Ploughing Championship every year. Talking to so many farmers in the one place provides an opportunity to evaluate new products and services as well as identify other weather-related needs.

The Agricultural Meteorology Unit continues to collaborate and support Teagasc, the Department of Agriculture, the Environmental Protection Agency and Irish academic institutes. The unit also helps to identify and coordinate Irish experts to represent Europe at WMO Commission for Agriculture Meteorology (CAgM) focus areas.

The AGMET group have increased their reach by moving to a greater online digital presence. They have relaunched their website www.agmet.ie and automated much of their administration through the use of digital subscription mailing lists. Following the suggestion by Tom Keane at the 2015 AGMET seminar (AGMET 2017), the Group have begun circulating digital newsletters. Tom sadly passed away in 2016. Thanks to his legacy and the many individuals and organisations who have collaborated so closely over the past number of decades, the future of Irish agrometeorology rests on a solid footing.

\section{Future of agrometeorology in Ireland}

Looking first to the short term, in 2017, Met Éireann released a high-resolution climate reanalysis dataset for Ireland (Gleeson et al. 2017). The short-term plan 
would be to use this 35-year dataset to update existing agrometeorological products while also developing new ones, as prioritised by the AGMET Group or otherwise. This numerical weather prediction (NWP) dataset will help drive agrometeorological research into the future.

There are ambitions to make greater use of the more centralised delivery of environmental products from Europe as well. More advantage could be made from the European Commission on Monitoring Agricultural Resources (European Commission [MARS] 2017) as well as the European Forest Fire Information System (European Commission [EFFIS] 2017). The arrival of the Copernicus programme is also a chance for Ireland to make greater use of remote sensing applications and climate service products (European Commission [Copernicus] 2017).

One aim of the Agricultural Meteorology Unit is to develop products that compare similar observations, NWP and remote sensing in one mutually quality controlling infrastructure. A system that can reliably show what has recently happened, what is happening and what is forecast to happen, including the accuracy of previous forecasts and how these conditions differ from normal, would carry significant confidence within the community.

In the longer term, agrometeorological activities in Ireland will largely be driven by European and national policy. The EU Areas of Natural Constraints Scheme (European Commission 2013), Water Framework Directive (European Commission 2000) and in particular the Nitrates Directive (European Commission 1991) are all helping to focus the direction of Irish agrometeorological research. The abolition of EU milk quotas (European Commission 2015) has opened the door for Ireland to increase herd capacity. Coupled with ambitious growth targets, as set out in national food strategies such as Food Wise 2025 (Dept. Agriculture, Food and the Marine 2015), grass growth and grass quality have become hot topics of research with the majority of this work being led by Teagasc.

However, the scaling up of agricultural activities also has the undesired consequence of scaling up greenhouse gas emissions. This causes difficulties for Ireland who are trying to meet internationally agreed greenhouse gas reduction targets (European Commission 2009). This, coupled with the fact that the Irish agricultural sector is currently developing a climate change adaption strategy (Dept. Agriculture, Food and the Marine 2016), will certainly pave the way for more debate on the severity of Irish agriculture's contribution towards global warming.

Whatever the future holds for agrometeorology in Ireland, it is likely that the AGMET Group will continue to liaise with government organisations and academia, and there will almost certainly be greater interaction with EU organisations and commercial companies. With a move towards a greater emphasis on SMART agriculture, Ireland's proud heritage in agrometeorology will prove a solid foundation to tackle future challenges and ambitions. By genuinely understanding the needs of farmers and bridging the gap between those needs and national and international policies, Ireland's agrometeorology will find its place in this ever-changing landscape. 


\section{Acknowledgements}

The author would like to thank Tom Keane and the AGMET Group for keeping excellent records of meetings and activities over the last three decades.

The author would also like to thank Mairéad Treanor, Librarian, Met Éireann - The Irish Meteorological Service, for helping to track down historic documents and digitising much of the earlier references.

\section{Disclosure statement}

No potential conflict of interest was reported by the author.

\section{References}

AGMET. 1985. First report. AGMET. Joint working group on applied agricultural meteorology. Dublin: AGMET; [accessed 2018 Sep 5]. http://edepositireland.ie/handle/2262/79765.

AGMET. 2017. Seminar 2015 AGMET; [accessed 2018 Sep 5]. http://agmet.ie/events/seminar-2015/. Bourke A. 1953. The potato blight weather warning service in Ireland in 1952. Irish Meteorological Service. Technical Note No. 13; [accessed 2018 Sep 5]. http://edepositireland.ie/handle/2262/ 70496.

Bourke A. 1993. The visitation of God, the potato and the Great Irish Famine. Dublin: The Lilliput Press.

Bourke A, Lamb H. 1993. The spread of potato blight in Europe in 1845-6 and the accompanying wind and weather patterns. Dublin: Irish Meteorological Service.

Collins J, Cummins T. 1996. Agroclimatic Atlas of Ireland. Dublin: AGMET.

Connaughton MJ 1969. Soil moisture deficits in Ireland in summer 1968. Agrometeorological Memorandum, Irish Meteorological Service; [accessed 2018 Sep 5]. http://edepositireland.ie/ handle/2262/71178.

Connaughton MJ 1970. Soil temperatures in Ireland. Agrometeorological Memorandum, Irish Meteorological Service; [accessed 2018 Sep 5]. http://edepositireland.ie/handle/2262/71180.

Connaughton MJ 1973a. Air frosts in late autumn and early winter. Agrometeorological Memorandum, Irish Meteorological Service; [accessed 2018 Sep 5]. http://edepositireland.ie/ handle/2262/71181.

Connaughton MJ 1973b. The grass-growing season in Ireland. Agrometeorological Memorandum, Irish Meteorological Service; [accessed 2018 Sep 5]. http://edepositireland.ie/handle/2262/ 71182 .

Dept. Agriculture, Food and the Marine. 2015. Food wise 2025. Dept. Agriculture, Food and the Marine; [accessed 2018 Sep 5]. https://www.agriculture.gov.ie/media/migration/foodindustryde velopmenttrademarkets/agri-foodandtheeconomy/foodwise2025/report/FoodWise2025.pdf.

Dept. Agriculture, Food and the Marine. 2016. Draft. Dept. Agriculture, food and the marine; [accessed 2018 Sep 5]. https://www.agriculture.gov.ie/ruralenvironmentandsustainability/clima techange/adaptation/.

Donnelly A, Proctor H, O'Connor B. 2013. Ireland's National Phenology Network. Environmental Protection Agency; [accessed 2018 Sep 5]. https://www.epa.ie/pubs/reports/research/climate/ CCRP_23_web_updated.pdf.

Dozeman J. 2001. Cold stress forecasting for sheep in Ireland. Dublin: AGMET.

European Commission. 1991. Council Directive 91/676/EEC of 12 December 1991 concerning the protection of waters against pollution caused by nitrates from agricultural sources. Off $\mathrm{J} \mathrm{L}$. 375:0001-0008.

European Commission. 2000. Directive 2000/60/EC of the European Parliament and of the Council establishing a framework for the Community action in the field of water policy. Off $\mathrm{J}$ L. 327:0001-0073. 
European Commission. 2009. Decision No 406/2009/EC of the European Parliament and of the Council of 23 April 2009 on the effort of Member States to reduce their greenhouse gas emissions to meet the Community's greenhouse gas emission reduction commitments up to 2020. Off J L. 140:136-148.

European Commission. 2013. Regulation (EU) No 1305/2013 of the European Parliament and of the Council of 17 December 2013 on support for rural development by the European Agricultural Fund for Rural Development (EAFRD) and repealing Council Regulation (EC) No 1698/2005. OJ L (Official Journal European Union L 347/487). 347:487-548.

European Commission. 2015. The EU milk sector prepares for the end of milk quotas. Press release. Brussels: European Commission; [accessed 2018 Sep 5]. http://europa.eu/rapid/press-release_IP15-4694_en.htm.

European Commission [Copernicus]. 2017 Homepage; [accessed 2018 Sep 5]. http://copernicus.eu/

European Commission [EFFIS]. 2017 Welcome to EFFIS; [accessed 2018 Sep 5]. http://effis.jrc.ec. europa.eu/.

European Commission [MARS]. 2017 MARS; [accessed 2018 Sep 5]. https://ec.europa.eu/jrc/en/ mars.

Gleeson E, Whelan E, Hanley J. 2017. Met Éireann high resolution reanalysis for Ireland. Adv Sci Res. 14:49-61.

Holden N. 2001. Agro-meteorological modelling - principles, data and applications. Dublin: AGMET. Irish Meteorological Service. 1965. Meteorological Service Annual Report. Irish Meteorological Service. Irish Meteorological Service. 1975. Meteorological Service Annual Report. Irish Meteorological Service. Irish Meteorological Service. 1983. Meteorological Service Annual Report. Irish Meteorological Service. Irish Meteorological Service. 1984. Meteorological Service Annual Report. Irish Meteorological Service. Irish Meteorological Service. 1986. Meteorological Service Annual Report. Irish Meteorological Service. Irish Meteorological Service. 1991. National Progress Report on Agrometeorology 1987-1990. World Meteorological Organisation (WMO) Commission for Agricultural Meteorology (CAgM).

Irish Meteorological Service - Met Éireann. 1971. The weather of January 1971. Agrometeorological Bulletin, Irish Meteorological Service; [accessed 2018 Sep 5]. https://www.met.ie/education/ publications/agrometeorological-bulletins.

Keane T, Collins J. 2004. Climate, weather and Irish agriculture. 2nd ed. Dublin: AGMET.

Keane T. 1982. Weather and potato blight. Agrometeorological Memorandum, Irish Meteorological Service; [accessed 2018 Sep 5]. http://edepositireland.ie/handle/2262/71185.

Keane T 2012. Establishment of the Meteorological Service in Ireland. The Foynes years, 1936-1945. Dublin: Irish Meteorological Service; [accessed 2018 Sep 5]. http://edepositireland. ie/handle/2262/72408

Kinealy C. 1994. This great calamity. Dublin: Gill \& Macmillan.

Koch E, Donelly A, Lipa W, Menzel A, Nekováŕ J. 2009. Final Scientific Report of COST 725. COST European Cooperation in the field of Scientific and Technical Research.

Murphy G, Holden N. 2001. Agrometeorological needs review and analysis for Ireland. Dublin: AGMET.

National Ploughing Association. 2017 Overview/background of event.; [accessed 2018 Sep 5]. http://www.npa.ie.

Nelson E. 1995. The cause of the calamity: the discovery of the potato blight in Ireland, 1845-1847, and the role of the National Botanic Gardens, Glasnevin, Dublin. Phytophthora Infestans. 150:111. Boole Press Ltd.

Ollerenshaw C. 1966. The approach to forecasting the incidence of fascioliasis over England and Wales 1958-1962. Agric Meteorology. 3:35-53.

Shields L. 1987. The Irish Meteorological Service: the first fifty years, 1936-1986. Dublin: Irish Meteorological Service.

Stein A, Draxler R, Stunder B, Cohen M, Ngan F. 2016. NOAA's HYSPLIT atmospheric transport and dispersion modeling system. Bull Amer Meteor Soc. 2059-2077. doi:10.1175/BAMS-D-14-00110.1

Thomas R 1978. Forecasting the onset of nematodiriasis in Sheep.Geneve: World Meteorological Organization. WMO Technical Note 159. 